\title{
POTENSI PRODUKSI GAS METANA DARI TANAH SAWAH TADAH HUJAN DI DAERAH PANTAI UTARA BAGIAN TIMUR JAWA TENGAH
}

\author{
A. Wihardjaka and E.S. Harsanti \\ Balai Penelitian Lingkungan Pertanian \\ Jl. Jakenan-Jaken Km 5 Kotak Pos 5 Jaken Pati 59182 Jawa Tengah e-mail : awihardjaka@yahoo.co.id
}

(Diterima tgl : 14 Juli 2011; Disetujui tgl : 2 Nov 2011)

\begin{abstract}
Alternate soil conditions under rainfed lowland affects soil methanogenesis. The oxidative soil condition could reduce methane gas formation, however, methanogenic bacteria is active to form methane gas under reductive soil condition. The laboratory experiment was carried out using incubation method to study production potency of methane in several soils of rainfed lowland in Central Java. Production potency of methane from Grumusols, Mediteran, and Nitosols was higher than in Aluvial and Planosols. Average methane production from rainfed lowland soils of Grumusols, Mediteran, Nitosols, Planosols, dan Aluvial was 0.15 - 0.96, $0.08-0.75,0.57,0.12$, and $0.05-0.17$ mg CH$/ \mathrm{g}$ soil, respectively. The contents of $\mathrm{P}_{2} \mathrm{O}_{5}, \mathrm{~K}_{2} \mathrm{O}$, and $\mathrm{SO}_{4}^{2-}$ in soil and $\mathrm{pH}$ increased significantly methane production in rainfed rice soils, whereas soil iron content correlated negatively with $\mathrm{CH}_{4}$ flux. Soil organic matter content tends increased methane production under rainfed lowland rice.
\end{abstract}

Keywords : methane production, rice soils, rainfed lowland

\begin{abstract}
ABSTRAK
Di ekosistem sawah tadah hujan, kondisi tanah selalu mengalami perubahan dari aerobik menjadi anaerobik secara silih berganti yang berpengaruh terhadap aktivitas metanogenesis dalam tanah. Kondisi tanah oksidatif menghambat pembentukan gas metana, sebaliknya kondisi tanah reduktif menguntungkan bakteri metanogen dalam pembentukan gas metana. Percobaan dilakukan di laboratorium dengan metode inkubasi untuk mengkaji potensi produksi gas metana dari tanah sawah tadah hujan. Potensi produksi gas metana pada tanah Grumusol, Mediteran, dan Nitosol lebih tinggi dibandingkan tanah Aluvial dan Planosol. Produksi gas metana rata-rata pada tanah Grumusol, Mediteran, Nitosol, Planosol, dan Aluvial masing-masing adalah 0,15 - 0,96;0,08 - 0,75;0,57;0,12; dan 0,05-0,17 $\mathrm{mg} \mathrm{CH} / \mathrm{g}$ tanah. Sifat-sifat tanah sawah tadah hujan yang berpengaruh nyata terhadap peningkatan produksi gas metana adalah $\mathrm{pH}$, kandungan $\mathrm{P}_{2} \mathrm{O}_{5}, \mathrm{~K}_{2} \mathrm{O}$, dan $\mathrm{SO}_{4}{ }^{2-}$ dalam tanah, sedangkan kandungan $\mathrm{Fe}$ dalam tanah berkorelasi negatif dengan fluks $\mathrm{CH}_{4}$. Kandungan bahan organik dalam tanah cenderung meningkatkan produksi gas metana.
\end{abstract}

Kata kunci : produksi metana, tanah sawah, sawah tadah hujan

\section{PENDAHULUAN}

Ketahanan pangan akhir-akhir ini dihadapkan pada kompleksnya permasalahan lingkungan, antara lain perubahan iklim dan alih fungsi lahan sawah beririgasi. Penciutan luasan sawah beririgasi sebagai andalan pemenuhan kebutuhan pangan nasional mendorong pemanfaatan lahan-lahan suboptimal antara lain sawah tadah hujan. Pemanfaatan sawah tadah hujan memberikan kontribusi dalam upaya mempertahankan dan meningkatkan produksi tanaman pangan pangan, terutama beras. Pengelolaan sawah tadah hujan berpengaruh terhadap laju produksi dan emisi gas rumah kaca terutama gas metana sebagai akibat perubahan kondisi tanah dari aerob menjadi anaerob secara bergantian dalam periode yang relatiflama. Kondisi tanah oksidatif tidak menguntungkan pembentukan gas metana, sebaliknya kondisi tanah reduktif sangat menguntungkan bakteri metanogen 
dalam menghasilkan gas metana.

Gas metana $\left(\mathrm{CH}_{4}\right)$ di troposfer merupakan salah satu gas rumah kaca yang berpotensi menyebabkan pemanasan bumi global. Gas metana di atmosfer 25-35 kali lebih efektif daripada $\mathrm{CO}_{2}$ sebagai gas rumah kaca Neue et al. (1990). IPCC (1992) melaporkan bahwa kadar metana sebesar 1,3 $\mathrm{ppm} \mathrm{CH}_{4}$ di atmosfer telah menyebabkan peningkatan suhu global $1,3{ }^{\circ} \mathrm{C}$. Emisi metana global tahunan diduga 420-620 Tg/tahun dan kadarnya meningkat 1 $\%$ hingga mencapai 1,7 ppm.

Gas metana dihasilkan oleh sekelompok bakteri anaerobik obligat Archaebacteria yang mempunyai struktur sel masih primitif. Bakteri ini memanfaatkan hasil perombakan selulose yang berupa asam formiat, asetat, methanol, metilamin, $\mathrm{CO}_{2}$ dan $\mathrm{H}_{2}$ yang diubah menjadi metana dalam kondisi anaerob (Cicerone \& Oremland, 1988). Menurut Neue \& Scharpenseel (1984), kondisi optimum pembentukan metana yaitu suhu optimum 30 $-40^{\circ} \mathrm{C}$, potensial redoks (Eh) tanah di bawah $-200 \mathrm{mV}$, dan $\mathrm{pH}$ optimum $6,4-7,8$.

Areal persawahan merupakan salah satu sumber emisi metana. Padi sawah dan lahan basah memberikan kontribusi $25-50 \%$ dari total emisi $\mathrm{CH}_{4}$ global. Di daerah perakaran tanaman padi, organisme pengoksidasi $\mathrm{CH}_{4}$ juga ditemukan yang bertindak sebagai rosot (sink) metana. Tanah sawah dengan karakteristik tertentu menguntungkan laju emisi $\mathrm{CH}_{4}$ (Crozier et al., 2000).

Proses termodinamika yang terjadi pada tanah tergenang yaitu reduksi $\mathrm{O}_{2}, \mathrm{NO}_{3}^{-}, \mathrm{Mn}^{4+}, \mathrm{Fe}^{3+}$, $\mathrm{SO}_{4}^{2-}$, dan $\mathrm{CO}_{2}$ menjadi $\mathrm{CH}_{4}$. Metabolisme senyawa $\mathrm{C}$ labil mungkin menghasilkan $\mathrm{CO}_{2}$, asetat, $\mathrm{H}_{2}$, dan memacu produksi $\mathrm{CH}_{4}$
(Yagi \& Minami, 1990). Pada kondisi tanah anaerobik, bakteri penghasil metana yang dikenal sebagai metanogen berkembang pesat terutama banyak dijumpai pada tanah-tanah tergenang. Tingkat dan lamanya kondisi anaerobik tersebut menentukan besarnya emisi gas metana, sedangkan kondisi tersebut ditentukan oleh rejim air (Crozier et al., 2000).

Laju perubahan Eh tanah akibat penggenangan ditentukan oleh kandungan liat, bahan organik dan besi tanah. Pada tanah yang banyak mengandung bahan organik dan liat, penggenangan dan pengolahan tanah menyebabkan perubahan redoks potensial dan $\mathrm{pH}$ tanah secara cepat, sehingga cepat sesuai bagi perkembangan bakteri pembentuk metana (Neue et al., 1990). Pada tanah dengan kandungan besi rendah dan bahan organik tinggi, penggenangan selama 2 minggu setelah pengolahan tanah dapat mengubah Eh tanah -200 hingga $-300 \mathrm{mV}$, sedangkan tanah dengan kandungan besi dan bahan organik tinggi menyebabkan perubahan Eh sangat lambat. Untuk mencapai Eh -200 $\mathrm{mV}$ diperlukan waktu lebih dari satu bulan penggenangan (Ponnamperuma, 1984).

Beberapa sifat tanah yang tidak menguntungkan bagi terbentuknya gas metana antara lain : (1) konduktivitas tanah $<4 \mathrm{mS} / \mathrm{cm}$ saat tergenang, (2) $\mathrm{pH}<6,5$, (3) mempunyai mineral feritik, gibsitik, feroginus atau oksidik, (4) mengandung liat kaolinit atau haloisit < $40 \%$, (5) kandungan liat $>18 \%$ pada regim kelembaban epiaquik. Kondisi demikian biasanya ditemukan pada jenis tanah Oksisol, Ultisol, dan beberapa jenis tanah Aridisol, Entisol, dan Inceptisol. Sedangkan jenis tanah yang diduga sesuai bagi pembentukan metana adalah ordo Entisol, Histosol, Inceptisol, 
Alfisol, Vertisol, dan Mollisol (Neue et al., 1990).

Produksi gas metana dari tanah sawah dapat digunakan sebagai salah satu pertimbangan dalam sistem budidaya tanaman padi berkelanjutan yang ramah lingkungan. Oleh karena itu, kegiatan penelitian diperlukan untuk mengkaji potensi produksi gas metana dari tanah sawah tadah hujan di sepanjang pantai utara bagian timur Jawa Tengah.

\section{BAHAN DAN METODE}

Percobaan dengan metode inkubasi dilaksanakan di laboratorium Emisi Gas Rumah Kaca Balai Penelitian Lingkungan Pertanian Jakenan pada tahun 2005. Beberapa contoh tanah sawah tadah hujan dari sentra produksi padi di Jawa Tengah diambil secara komposit pada kedalaman lapisan olah (0-15 $\mathrm{cm})$. Sebanyak 12 contoh tanah diambil di tiga kabupaten yang telah menerapkan pola tanam padi gogorancah - padi walik jerami palawija atau bera yaitu Pati, Rembang, dan Blora. Lokasi pengambilan contoh ditetapkan berdasarkan peta jenis tanah skala 1:250.000 dan hasil prasurvei di lapangan.

Contoh tanah dikeringanginkan, ditumbuk, dan diayak dengan saringan berdiameter lubang 2 $\mathrm{mm}$. Sebagian contoh tanah dianalisis sifat fisik dan kimia tanah yang meliputi tekstur, $\mathrm{pH}$, kandungan $\mathrm{C}$-organik, Fe terekstrak asam sitrat, KTK, kation mudah tereduksi, $\mathrm{NO}_{3}^{-}$, dan $\mathrm{SO}_{4}{ }^{2-}$ dengan menggunakan metode baku.

Untuk keperluan inkubasi, contoh tanah sebanyak 20 gram (ukuran 80 mesh) dimasukkan ke dalam gelas piala $100 \mathrm{ml}$, dan ditambahkan $40 \mathrm{ml}$ air destilasi. Labu piala ditutup dengan penutup karet (rubber stopper) yang dilengkapi dengan saluran untuk pemasukan gas $\mathrm{N}_{2}$, septum tempat pengambilan contoh gas dan tempat elektroda platinum. Gas $\mathrm{N}_{2}$ dialirkan dengan kecepatan $250 \mathrm{ml} /$ menit ke dalam gelas piala sambil dilakukan pengocokan selama 3 menit. Contoh tanah diinkubasi selama 10 hari pada suhu tertentu $\left(25^{\circ} \mathrm{C}\right)$. Sehari sebelum pengambilan contoh, gas $\mathrm{N}_{2}$ dialirkan lagi ke dalam gelas piala 100 ml selama 2 menit. Pada saat pengambilan contoh, pengocokan dilakukan lagi selama 3 menit. Contoh gas dalam gelas piala diambil sebanyak $5 \mathrm{ml}$ dengan menggunakan injektor volume $5 \mathrm{ml}$. Saat pengambilan contoh gas, injektor ditarik dan ditekan sebanyak 10 kali untuk mencampur gas yang berada di dalam gelas piala. Kemudian contoh gas dianalisis konsentrasi metananya dengan menggunakan kromatografi gas Shimadzu model 6C-8A.

\section{Penetapan Potensi Produksi $\mathrm{CH}_{4}$}

Contoh gas pada saat $\mathrm{t}_{0}$ diambil menggunakan injektor $5 \mathrm{ml}$, dan kadar metana saat $\mathrm{t}_{0}$ dipertimbangkan sebagai $\mathrm{C}_{0}$. Setiap akan mengambil contoh gas, ke dalam gelas piala inkubasi diaduk dan dialiri $\mathrm{N}_{2}$ selama 2 menit dengan kecepatan alir $250 \mathrm{ml} /$ menit. Setelah 24 jam inkubasi, contoh gas diambil lagi dan dipertimbangkan sebagai $\mathrm{C}_{24}$. Perbedaan kadar antara $\mathrm{C}_{24}$ dan $\mathrm{C}_{0}$ dipandang sebagai laju produksi $\mathrm{CH}_{4}$ per hari. Setelah pengambilan contoh gas pada $\mathrm{C}_{24}$, gas $\mathrm{N}_{2}$ dialirkan lagi ke gelas piala inkubasi dan dilakukan pengadukan selama 2 menit dan kemudian proses inkubasi dilanjutkan. Pengambilan contoh gas sebaiknya dilakukan setiap interval 4 hari hingga waktu inkubasi yang ditentukan.

Kadar $\mathrm{CH}_{4}$ dianalisis menggunakan 
kromatografi gas (GC) yang dilengkapi dengan flame ionization detector (FID) dan kolom N porapak 3m 80/100 mesh. Kondisi alat kromatografi gas untuk pengukuran fluks metana yaitu (1) gas pembawa (carrier) $\mathrm{N}_{2}$ dengan laju alir $30 \mathrm{ml} / \mathrm{menit}$, (2) tekanan udara dan $\mathrm{H}_{2} 5$ bar, (3) suhu injeksi $80^{\circ} \mathrm{C}$, (4) suhu kolom $110{ }^{\circ} \mathrm{C}$. Gas metana staandar dengan kadar 10,1 ppm $\mathrm{CH}_{4}$ secara teratur dianalisis sebagai kalibrasi melalui alat kromatografi gas.

Laju produksi metana diukur menggunakan persamaan yang digunakan oleh Lantin et al.

$$
\mathrm{E}=\left(\mathrm{C}_{24}-\mathrm{C}_{0}\right) \cdot \frac{\mathrm{Vh}}{20} \cdot \frac{\mathrm{mW}}{\mathrm{mV}} \cdot \frac{273,2}{(273,2+\mathrm{T})}
$$

(1995), sebagai berikut :

dimana :

E : produksi $\mathrm{CH}_{4}(\mathrm{mg} / \mathrm{g}$ tanah/hari)

$\mathrm{C}_{0}:$ kadar $\mathrm{CH}_{4}$ pada saat $\mathrm{t}_{0}(\mathrm{ppm})$

$\mathrm{C}_{24}$ : kadar $\mathrm{CH}_{4}$ saat 24 jam setelah inkubasi (ppm)

$\mathrm{Vh}$ : volume headspace dalam gelas piala inkubasi (ml)

$\mathrm{mW}$ : bobot molekul $\mathrm{CH}_{4}(\mathrm{~g})$

$\mathrm{mV}$ : volume molekul $\mathrm{CH}_{4}(22,41$ pada suhu \& tekanan standar dalam mol/l)

$\mathrm{T}$ : suhu rata-rata inkubator $\left({ }^{\circ} \mathrm{C}\right)$

\section{HASIL DAN PEMBAHASAN}

Karakteristik Tanah Sawah Tadah Hujan

Tanah sawah tadah hujan di sepanjang pantai utara Jawa Tengah umumnya mempunyai kandungan bahan organik rendah, dimana kandungan $\mathrm{C}$ organik kurang dari $1 \%$ dan kandungan $\mathrm{N}$ total kurang dari $0,10 \%$ (Tabel 1). Keberhasilan pola tanam di areal sawah tadah hujan selain tergantung pada ketersediaan hara dan air juga ditentukan oleh kandungan bahan organik dalam tanah.

Beberapa contoh tanah sawah tadah hujan mempunyai kandungan liat lebih dari $20 \%$, sehingga berpengaruh terhadap ketersediaan hara-hara esensial bagi tanaman padi khususnya. Peningkatan kandungan liat akan meningkatkan kapasitas tukar kation (KTK) dan kandungan $\mathrm{P}_{2} \mathrm{O}_{5}$ dan $\mathrm{K}_{2} \mathrm{O}$ terekstrak $\mathrm{HCl}$ $25 \%$. Tanah-tanah yang berasal dari Blora mempunyai KTK lebih dari $25 \mathrm{me} / 100 \mathrm{~g}$ atau relative termasuk kategori tinggi, sedangkan yang berasal dari Pati dan Rembang umumnya mempunyai KTK rendah kecuali jenis tanah Grumusol.

Kandungan nitrat dan sulfat pada tanah-tanah yang berasal dari Pati umumnya lebih rendah daripada yang berasal dari Rembang, dan tanah dari Rembang juga lebih rendah daripada yang berasal dari Blora. Tingginya nitrat dapat berpeluang terjadinya pencemaran nitrat dalam air, diduga akibat penggunaan pupuk nitrogen di tingkat petani yang tinggiStatus 
Tabel 1. Karakteristik beberapa tanah sawah tadah hujan di daerah pantai utara bagian timur Jawa Tengah tahun 2005

\begin{tabular}{|c|c|c|c|c|c|c|c|c|c|c|c|c|}
\hline Asal contoh tanah & $\begin{array}{c}\text { C- } \\
\text { orga } \\
\text { nik } \\
(\%)\end{array}$ & $\begin{array}{l}\mathrm{N} \\
\text { total } \\
(\%)\end{array}$ & $\begin{array}{c}\mathrm{NO}_{3} \\
(\mathrm{ppm})\end{array}$ & $\begin{array}{c}\mathrm{P}_{2} \mathrm{O}_{5}- \\
\mathrm{HCl} 25 \% \\
(\mathrm{ppm})\end{array}$ & $\begin{array}{c}\mathrm{K}_{2} \mathrm{O}-\mathrm{HCl} \\
25 \% \\
(\mathrm{ppm})\end{array}$ & $\begin{array}{c}\mathrm{SO}_{4} \\
(\mathrm{ppm})\end{array}$ & $\begin{array}{c}\mathrm{Fe} \\
(\mathrm{ppm})\end{array}$ & $\begin{array}{c}\mathrm{Mn} \\
(\mathrm{ppm})\end{array}$ & $\begin{array}{c}\text { KTK } \\
\text { (me/ } \\
100 \\
\text { g) }\end{array}$ & $\begin{array}{c}\text { Pasir } \\
(\%)\end{array}$ & $\begin{array}{l}\text { Debu } \\
(\%)\end{array}$ & $\begin{array}{l}\text { Liat } \\
(\%)\end{array}$ \\
\hline Jaken, Pati & 0,84 & 0,09 & 423,2 & 88,7 & 156,0 & 49,7 & 118,7 & 32,6 & 13,5 & 33,7 & 63,0 & 3,3 \\
\hline Jakenan Pati & 0,22 & 0,02 & 604,5 & 111,6 & 78,0 & 112,3 & 132,1 & 13,6 & 7,9 & 41,4 & 51,4 & 7,2 \\
\hline Pucakwangi Pati & 0,38 & 0,04 & 554,0 & 87,0 & 78,0 & 82,1 & 133,8 & 47,8 & 6,8 & 46,0 & 42,0 & 12,0 \\
\hline Mojoagung Pati & 0,38 & 0,04 & 664,9 & 162,5 & 390,0 & 45,4 & 130,1 & 77,4 & 15,8 & 23,9 & 50,5 & 25,6 \\
\hline Sumber Rembang & 0,76 & 0,06 & 725,4 & 88,7 & 78,0 & 41,0 & 127,7 & 73,0 & 14,3 & 26,2 & 51,3 & 22,5 \\
\hline Landoh Rembang & 0,22 & 0,02 & 725,4 & 70,6 & 292,5 & 97,2 & 106,8 & 67,7 & 18,0 & 21,1 & 63,4 & 15,6 \\
\hline Sulang Rembang & 0,46 & 0,04 & 544,0 & 338,2 & 780,0 & 142,6 & 5,6 & 12,4 & 27,4 & 2,8 & 75,6 & 21,6 \\
\hline Sluke Rembang & 0,22 & 0,02 & 1027,6 & 405,5 & 546,0 & 77,8 & 135,8 & 129,7 & 23,7 & 10,5 & 43,3 & 46,2 \\
\hline Kunduran Blora & 0,38 & 0,03 & 967,2 & 101,8 & 312,0 & 32,4 & 131,4 & 58,3 & 25,9 & 18,8 & 35,6 & 45,6 \\
\hline Ngawen Blora & 0,30 & 0,03 & 1027,6 & 159,2 & 136,5 & 38,9 & 133,2 & 110,4 & 29,3 & 19,6 & 49,6 & 30,8 \\
\hline Jepon Blora & 0,83 & 0,05 & 1148,6 & 205,2 & 507,0 & 56,2 & 12,1 & 4,4 & 48,1 & 6,0 & 60,6 & 33,4 \\
\hline Medang Blora & 0,99 & 0,09 & 1088,1 & 234,8 & 643,5 & 254,9 & 124,5 & 108,4 & 26,3 & 4,9 & 34,9 & 60,2 \\
\hline
\end{tabular}

$\mathrm{P}_{2} \mathrm{O}_{5}$ dalam tanah dari beberapa lokasi di Pati dan Rembang adalah rendah terutama pada tanah Aluvial dan Planosol. Namun status $\mathrm{P}_{2} \mathrm{O}_{5}$ dalam tanah Grumusol, Mediteran, dan Nitosol termasuk kategori sedang dimana konsentrasi $\mathrm{P}_{2} \mathrm{O}_{5}$ lebih dari 200 ppm. Tanahtanah yang diambil dari Rembang dan Blora umumnya mempunyai status $\mathrm{K}_{2} \mathrm{O}$ terekstrak $\mathrm{HCl} 25 \%$ lebih tinggi daripada yang berasal dari Pati. Kandungan $\mathrm{K}_{2} \mathrm{O}$ yang tinggi terdapat pada tanah-tanah Grumusol, Nitosol, dan Mediteran dengan kisaran 200 - 400 ppm atau kategori sedang - tinggi (Tabel 1).

\section{Potensi Produksi Gas Metana}

Pada Gambar 1 terlihat bahwa peningkatan produksi gas metana umumnya terjadi saat 13 hari inkubasi, dimana fluks gas metana pada tanah sawah dari Pati adalah lebih rendah daripada tanah-tanah dari Rembang dan Blora. Pada tanah sawah dari Pati, puncak produksi terjadi pada hari ke-13 untuk tanah Grumusol dan hari ke-17 untuk tanah Planosol, sedangkan tanah Aluvial dari Jaken mengalami peningkatan nyata setelah diinkubasi selama 21 hari. Penurunan produksi justeru terjadi pada tanah Aluvial dari Jakenan. Pada tanah-tanah yang berasal dari Rembang dan Blora umumnya terjadi kenaikan produksi gas metana setelah hari ke-13 inkubasi, dimana fluks gas metana pada tanah Aluvial lebih rendah daripada tanah-tanah lainnya.

Pemberian sumber energi berupa larutan gula (glukosa) pada awal inkubasi mengakibatkan metana yang dihasilkan relatif tinggi karena bakteri metanogen menggunakannya untuk metabolisme sebelum mampu memanfaatkan bahan organik tanah. Namun setelah itu, fluks yang dihasilkan turun diduga akibat makin menipisnya senyawa organik segar yang ditambahkan (glukosa), tetapi lambat laun fluks metana meningkat setelah bakteri tersebut menggunakan bahan organik tanah sebagai sumber energinya. 

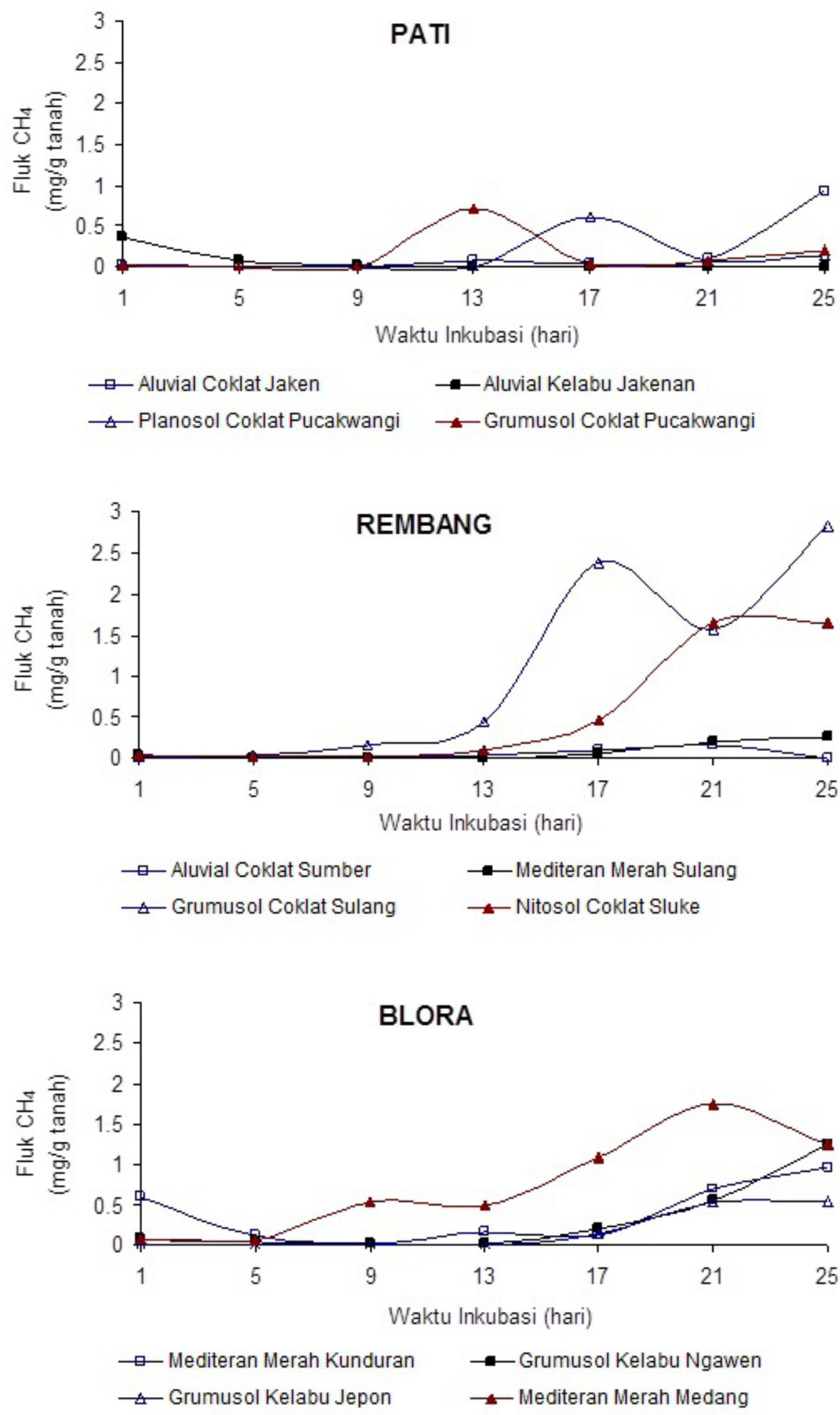

Gambar 1. Pola produksi gas metana pada beberapa tanah sawah tadah hujan di Jawa Tengah tahun 2005 
Keragaman potensi produksi gas metana pada jenis atau tipe tanah yang berbeda ditentukan oleh berbagai faktor, antara lain : kondisi agrohidrologi, praktek budidaya, dan sifat fisiko kimia tanah. Pada jenis tanah yang sama belum tentu mempunyai potensi produksi gas metana sama. Tanah Aluvial relatif mempunyai potensi produksi $\mathrm{CH}_{4}$ lebih rendah daripada tanah Grumusol, Mediteran, dan Nitosol (Gambar 2). Hasil analisis di laboratorium menunjukkan bahwa potensi produksi gas metana rata-rata pada tanah Grumusol lebih tinggi daripada tanah Mediteran, Nitosol, Planosol, dan Aluvial dengan nilai fluks masing-masing 0,1513 - 0,9629; 0,0806 0,$7529 ; 0,5665 ; 0,1232$; dan $0,0483-0,1672$ $\mathrm{mg} \mathrm{CH}_{4} / \mathrm{g}$ tanah (Gambar 2). Menurut Neue \& Roger (1994), produksi metana pada tanah alkali (pH 8,2 ; 1,5 \% C organik; KTK 10,2 me/100 g) terjadi dalam waktu satu jam setelah inkubasi, sedangkan produksi metana pada tanah kapuran ( $\mathrm{pH} 7,4 ; 1,6 \%$ C organik; KTK 30,4 me/100 g) mencapai maksimum sekitar 2 minggu setelah inkubasi. Pada tanah masam (pH 4,0; 2,6 \% C organik; KTK 17,9 me/100 $\mathrm{g})$, produksi metana tertunda dan puncaknya terjadi setelah 5 minggu diinkubasi saja. Pada tanah sangat masam, metana mungkin tidak terbentuk sepanjang waktu.

Fluk $\mathrm{CH}_{4}$ kumulatif tertinggi ditunjukkan pada tanah Grumusol dari Rembang dan diikuti pada tanah Mediteran dari Blora. Fluk $\mathrm{CH}_{4}$ kumulatif dari tanah sawah tadah hujan di Pati adalah lebih rendah dibandingkan tanah sawah tadah hujan dari Rembang dan Blora (Gambar 2). Produksi gas metana di lahan tadah hujan akibat kondisi basah kering silih berganti memberikan peluang limbung metana lebih besar dibandingkan di lahan sawah beririgas, dan jenis dan sifat tanah berpengaruh terhadap besarnya emisi gas metana. Emisi gas $\mathrm{CH}_{4}$ dari tanah Latosol dengan inkubasi macak-macak adalah lebih tinggi $87,9 \%$ dibandingkan dengan tanah Alluvial. Kondisi tanah tergenang, gas $\mathrm{CH}_{4}$ terlepas ke atmosfir dari tanah Latosol adalah lebih tinggi 67,9\% dibandingkan dengan dari tanah Alluvial (Setyanto \& Abubakar, 2006). Indikator nyata dari tingginya fluks metana adalah $\mathrm{pH}$ tanah. Peningkatan $\mathrm{pH}$ tanah mendekati netral cenderung meningkatkan fluks metana, seperti Grumusol dari Sulang Rembang mempunyai potensi produksi metana tertinggi $\left(0,96 \mathrm{mg} \mathrm{CH}_{4} / \mathrm{g}\right.$ tanah) pada $\mathrm{pH}$ 6,45 diikuti Mediteran dari Medang Blora (fluks $0,75 \mathrm{mg} \mathrm{CH}_{4} / \mathrm{g}$ tanah) pada $\mathrm{pH}$ 6,28 dan Nitosol dari Sluke Rembang (fluks 0,57 $\mathrm{mg} \mathrm{CH}_{4} / \mathrm{g}$ tanah) pada $\mathrm{pH}$ 5,42. Namun pada $\mathrm{pH}$ rendah, potensi produksi gas metana cenderung rendah yang ditunjukkan pada tanah Aluvial dengan fluks $0,05-0,17 \mathrm{mg}$ $\mathrm{CH}_{4} / \mathrm{g}$ tanah $(\mathrm{pH} 4,92-5,16)$ dan Planosol dengan fluks $0,12 \mathrm{mg} \mathrm{CH}_{4} / \mathrm{g}$ tanah pada $\mathrm{pH}$ 5,04 (Gambar 3). Menurut Parashar et al. (1991), laju emisi metana tertinggi tercapai pada tanah dengan $\mathrm{pH} 8,2$. 

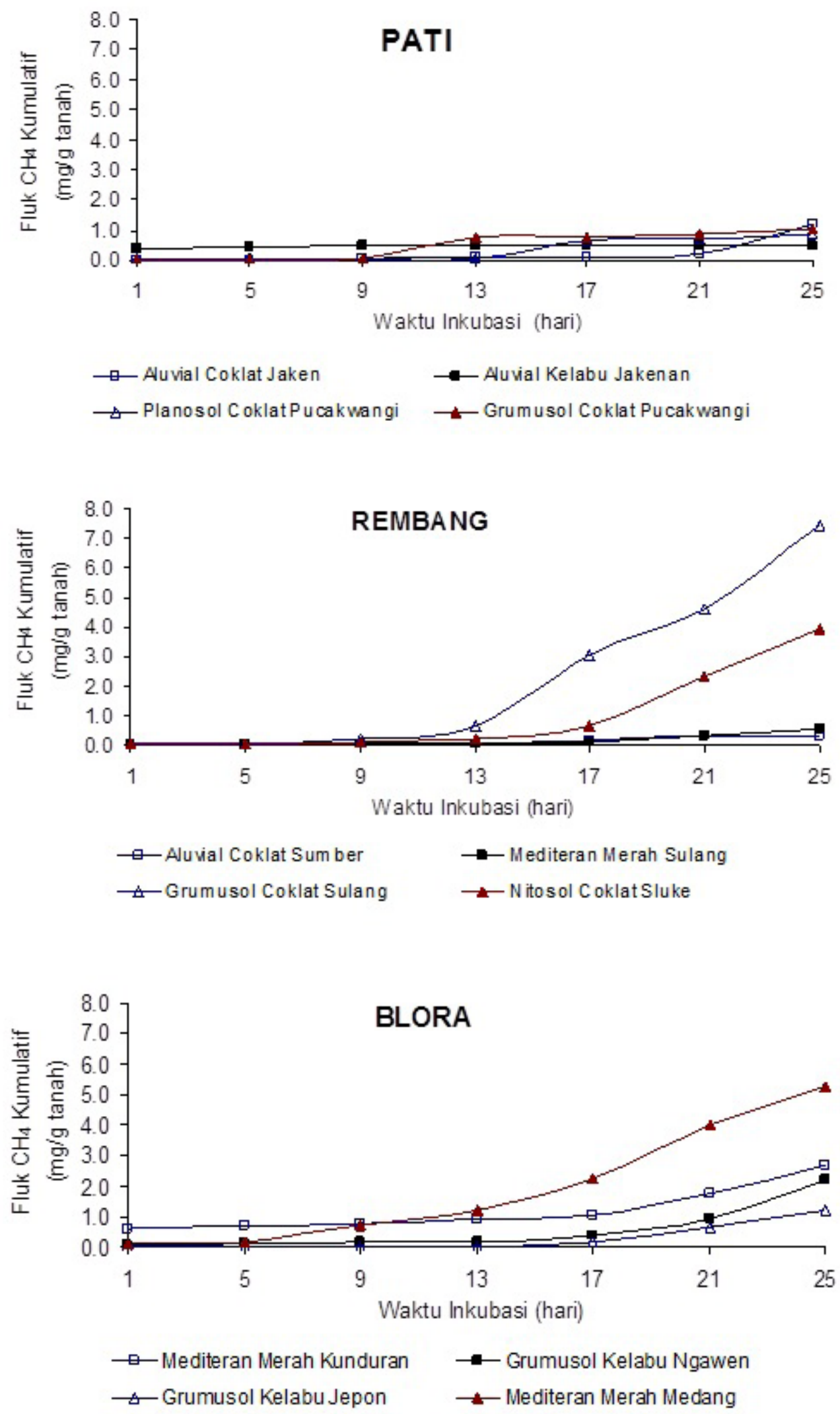

Gambar 2. Fluk kumulatif gas metana dari beberapa tanah sawah tadah hujan di daerah pantai utara bagian timur Jawa Tengah 
Beberapa sifat kimia tanah yang nyata meningkatkan fluks metana di lahan sawah tadah hujan adalah $\mathrm{pH}$, kandungan $\mathrm{P}_{2} \mathrm{O}_{5}, \mathrm{~K}_{2} \mathrm{O}$, dan $\mathrm{SO}_{4}{ }^{2-}$ (Gambar 3). Hubungan positif antara produksi $\mathrm{CH}_{4}$ dan $\mathrm{pH}$ ataupun kandungan $\mathrm{SO}_{4}^{2-}$ dalam tanah nyata pada taraf 0,05 , sedangkan hubungan positif antara produksi $\mathrm{CH}_{4}$ dan kandungan $\mathrm{P}_{2} \mathrm{O}_{5}$ ataupun $\mathrm{K}_{2} \mathrm{O}$ dalam tanah nyata pada taraf 0,01 . Hubungan negatif terjadi antara fluks $\mathrm{CH}_{4}$ dan kandungan besi dalam tanah. Tingginya kandungan besi dalam tanah dapat menghambat pembentukan gas metana. Kandungan $\mathrm{C}$ organik, $\mathrm{N}$ total, $\mathrm{NO}_{3}^{-}$, KTK dan liat dengan fluks $\mathrm{CH}_{4}$ adalah tidak nyata, namun ada kecenderungan bahwa peningkatan ketersediaannya akan mempertinggi produksi gas metana. Rendahnya produksi gas metana pada kondisi aerob disebabkan oleh mineralisasi bahan organik tanah menjadi $\mathrm{CO}_{2}$ lebih tinggi dibandingkan menjadi $\mathrm{CH}_{4}$ (Neue et al., 1990). Redoks potensial merupakan salah satu sifat fisikokimia yang mempengaruhi laju produksi metana dalam tanah sawah. Beberapa senyawa yang berperan dalam reaksi redoks seperti $\mathrm{NO}_{3}^{-}, \mathrm{Mn}, \mathrm{Fe}$, dan $\mathrm{SO}_{4}^{2-}$ pada kondisi tanah tereduksi atau anaerobik memberikan kontribusi terhadap terbentuknya gas metana (Crozier et al., 2000). Hubungan produksi metana dan senyawasenyawa tersebut dalam tanah sawah tadah hujan digambarkan dengan persamaan regresi berganda $\mathrm{CH}_{4}=0,502-0,0002 \mathrm{NO}_{3}^{-}+0,0049$ $\mathrm{Mn}-0,0047 \mathrm{Fe}+0,0022 \mathrm{SO}_{4}^{2-}\left(\mathrm{R}^{2}=0,64\right)$. Peningkatan produksi metana ditentukan oleh tingginya sulfat dan $\mathrm{Mn}$, dan rendahnya Fe dan nitrat dalam tanah. Produksi metana optimum terjadi pada potensial redoks kurang dari - $150 \mathrm{mV}$. Pada kondisi tanah reduktif tersebut, besarnya metana yang dihasilkan ditentukan oleh jumlah dan laju dekomposisi substrat organik mudah terombak, jumlah dan jenis nitrat tereduksi, oksida besi dan mangan, sulfat, dan senyawa organik (Neue et al., 1990).
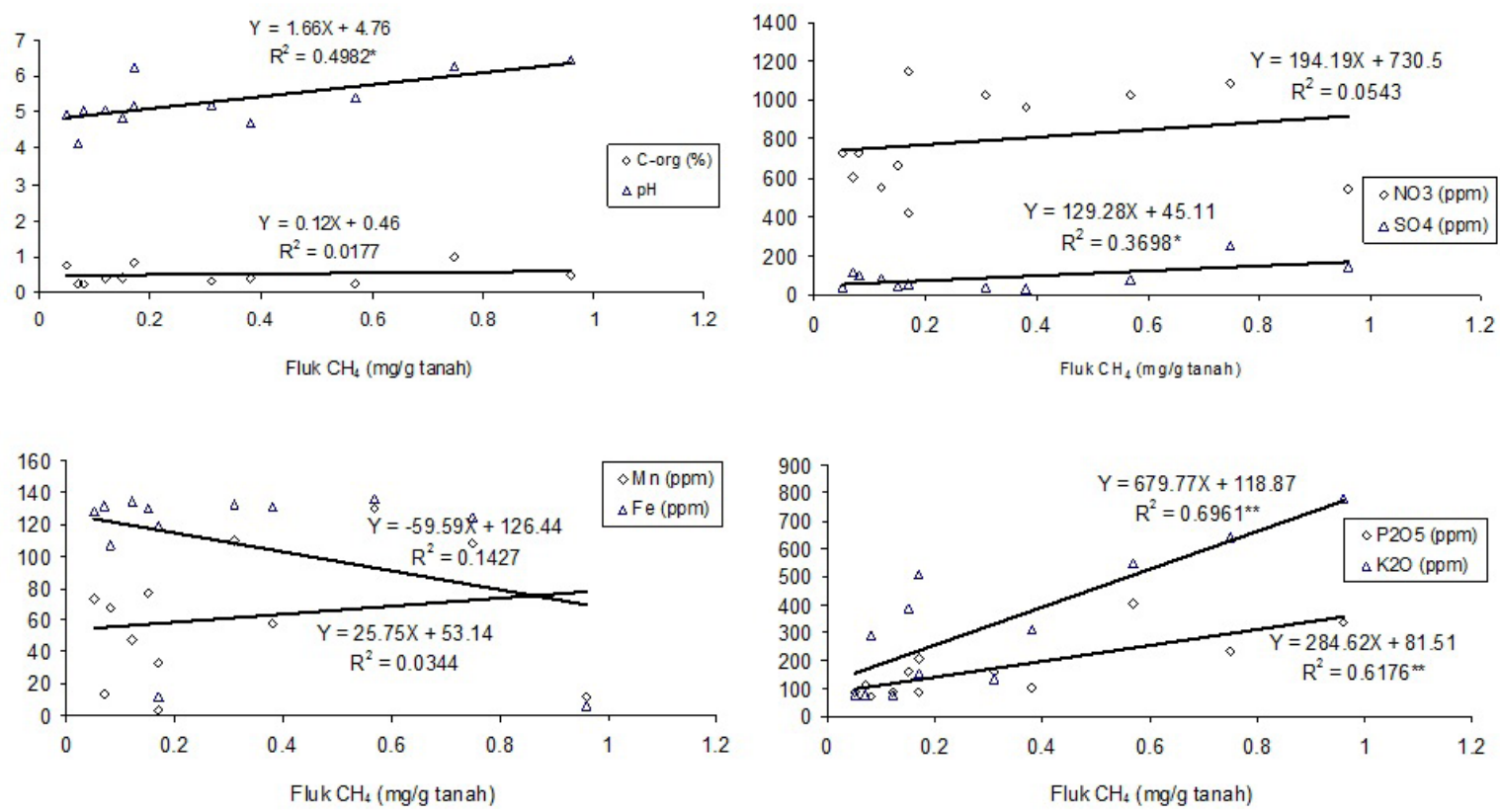

Gambar 3. Hubungan antara produksi gas metana dengan beberapa parameter kimia 
Korelasi positif antara fluks metana dan kandungan $\mathrm{C}$ organik ditentukan oleh tingkat dekomposisi dan kondisi tanah sawah. Penggenangan tanah sawah tadah hujan seringkali disamakan dengan penundaan dekomposisi bahan organik. Namun tanah sawah di tropis menjadi tanah basah dengan suhu tinggi di semua musim menunjukkan adanya proses mineralisasi cepat dan humifikasi lemah (Bonneau cit Neue \& Roger, 1994). Potensi produksi metana dari tanah sawah menjadi tinggi disebabkan oleh rendahnya tingkat humifikasi. Tingkat humifikasi rendah ditunjukkan oleh kandungan $\mathrm{H}_{2}$ dan $\mathrm{N}$ lebih rendah, kandungan gugus karboksil dan fenolik lebih rendah, dan kandungan gugus alkoholik dan ametoksil lebih tinggi (Tsutsuki \& Kumada, 1980).

Peningkatan produksi $\mathrm{CO}_{2}$ menurunkan pembentukan metana akibat kurangnya asam-asam organik yang dihasilkan selama proses mineralisasi bahan organik (Neue \& Scharpenseel, 1984). Nisbah pembentukan $\mathrm{CO}_{2}$ dan $\mathrm{CH}_{4}$ dipengaruhi oleh nisbah kapasitas oksidasi yang mencakup jumlah $\mathrm{O}_{2}$ tereduksi, $\mathrm{NO}_{3}^{-}, \mathrm{Mn}^{4+}, \mathrm{Fe}^{3+}$ menjadi kapasitas reduksi (Takai cit Neue \& Roger, 1994). Akumulasi $\mathrm{CO}_{2}$ dalam jumlah besar mempengaruhi kesetimbangan kimiawi hampir semua kation bivalen $\left(\mathrm{Ca}^{2+}, \mathrm{Mg}^{2+}, \mathrm{Fe}^{2+}\right.$, $\mathrm{Mn}^{2+}, \mathrm{Zn}^{2+}$ ) dan produksi metana pada tanah tergenang (Parashar et al., 1991).

Sifat tanah lainnya yang berpengaruh pada besarnya emisi gas metana adalah tekstur tanah. Tingkat perkolasi yang tinggi pada tanah berlempung dan berpasir dapat menghambat proses reduksi dan pembentukan metana, serta banyaknya pencucian metana terlarut ke lapisan yang lebih dalam (Wang et al., 1993). Pada tanah dengan kandungan liat tinggi dapat memberikan fluks metana rendah akibat metana terperangkap mengalami oksidasi sebelum terlepas ke atmosfir.

Tanah-tanah sawah dengan potensi produksi metana tinggi akan memberikan kontribusi terhadap tingginya emisi metana. Pemanfaatan tanah sawah dengan potensi produksi metana tinggi untuk budidaya tanaman padi sawah seharusnya melibatkan komponen-komponen teknologi mitigasi emisi metana, antara lain dengan menerapkan irigasi berselang, penggunaan varietas padi rendah emisi, pemberian pembenah organik tanah dengan nisbah $\mathrm{C} / \mathrm{N}$ rendah, dan penerapan tanam benih langsung (tabela) (Setyanto \& Abubakar, 2006).

\section{KESIMPULAN}

Potensi produksi gas metana dari tanah sawah Grumusol, Mediteran, dan Nitosol lebih tinggi daripada tanah Aluvial, dan Planosol di sepanjang pantai utara Jawa Tengah.

Produksi gas metana makin tinggi pada pH mendekati netral, dan menurun dengan meningkatnya kemasaman tanah.

Sifat-sifat tanah yang menentukan peningkatan produksi metana secara nyata dari tanah sawah tadah hujan di daerah pantai utara Jawa Tengah bagian timur adalah kandungan $\mathrm{P}_{2} \mathrm{O}_{5}, \mathrm{~K}_{2} \mathrm{O}$, $\mathrm{SO}_{4}{ }^{2-}$ dalam tanah, dan reaksi tanah $(\mathrm{pH})$.

Pengelolaan tanah sawah dengan potensi produksi tinggi untuk budidaya padi sawah seharusnya melibatkan komponen-komponen teknologi mitigasi emisi metana. 


\section{UCAPAN TERIMA KASIH}

Pada kesempatan ini, ucapan terima kasih penulis sampaikan kepada sdr. Titi Sopiawati dan Sarwoto yang telah membantu dalam pelaksanaan percobaan di laboratorium.

\section{DAFTAR PUSTAKA}

1. Cicerone, R.J., and R.S. Oremland. 1988. Biogeochemical aspects of atmospheric methane. Global Biogeochem. Cycles 2 : 299-327.

2. Crozier, C.R., R.D. DeLaune, and W.H. Patrick, Jr. 2000. Methane production in Mississippi deltaic plain wetland soils as a function of soil redox species. p. 247-455 in Lal, R., J. Kimble, E. Levine, B.A. Stewart (eds.). Soil and Global Change. CRC Press. Boca Raton, Florida.

3. IPCC. 1992. Methane emission and opportunities for control : workshop results of Intergovermental Panel on Climate Change. JAE \& EPA. September 1991.

4. Lantin, R.S., J.B. Aduna, and A.M.J. Javellana. 1995. Methane measurements in rice fields. Instruction manual and methodologies, maintenance and troubleshooting guide. A joint undertaking by International Rice Research Institute (IRRI), United State Environmental Protection Agency (USEPA) and United Nations Development Program (UNDP), Maxwell, MA.

5. Neue, H.U., and P.A. Roger. 1994. Potential of methane emission in major rice ecologies. p. 65 - 92 in Zepp, R.G. (ed.). Climate Biosphere Interaction : Biogenic Emissions and Environmental Effects of Climate Change. John Wiley and Sons, New York.
6. Neue, H.U., and H.W. Scharpenseel. 1984. Gaseous product of the decomposition of organic matter in submerged soils. p. $311-328 \underline{\text { in }}$ Organic Matter \& Soil. International Rice Research Institute. Los Banos, Laguna, Philippines.

7. Neue, H.U., P. Becker-Heidmann, and H.W. Scharpenseel. 1990. Organic matter dynamics, soil properties, and cultural practices in ricelands and their relationship to methane production. $\mathrm{p}$. 457 - 466 in Bouwman, A.F. (Ed.). Soil and The Greenhouse Effect. Wiley. Chichester, U.K.

8. Parashar, D.C., J. Rai, P.K. Gupta, and N. Singh. 1991. Parameters affecting methane emission from paddy fields. Indian J. Radio and Space Physics. 20 : $12-17$.

9. Ponamperuma, F.N. 1984. Straw as source of nutrients for wetland rice. $p$. 311 - 328 in Organic Matter and Rice. International Rice Research Institute. Los Banos, Laguna, Philippines.

10. Setyanto, P., and R. Abubakar. 2006. Evaluation of methane emission and potential mitigation from flooded rice field. Jurnal Litbang Pertanian 25(4) : 139-148.

11. Tsutsuki, K., and K. Kumada. 1980. Chemistry of humic acids. Fertilizer Science $3: 9-171$.

12. Wang, Z.P., C.W. Lindau, R.D. De Laune, and W.H. Patrick Jr. 1993. Methane production from anaerobic soil amended with rice straw and nitrogen fertilizers. Fertilizer Research $33: 115-121$. 


\title{
PENURUNAN KONSENTRASI KROMIUM (Cr) DALAM LIMBAH CAIR ELECTROPLATING DENGAN PENGGUNAAN KOAGULAN DAN ADSORBEN
}

\author{
Ratih Artanti, Dedi Nursyamsi, Sigit Yuli Jatmiko ${ }^{1}$
}

(Diterima tanggal:

; Disetujui tanggal:

)

\begin{abstract}
The research was conducted at the Integrated Laboratory, Indonesian Agricultural Environment Research Institute (IAERI), Jakenan, Pati, Central Java. Treatment for electroplating wastewater samples taken from Talang Subdi strict, Tegal District, Central Java was managed as chemically that was through the coagulation and flocculation processes. The purpose of this study was to test the effectiveness of coagulant and adsorbent materials in reducing the concentration of electroplating wastewater Cr. Experiments used a factorial design in randomized completely block design and three replications. The first factor was the coagulant materials, namely: control, alum $\mathrm{Al}_{2} \mathrm{SO}_{4}$. $\left.\mathrm{xH}_{2} \mathrm{O}\right)$ ), sodium bisulphate ( $\mathrm{NaHSO}$ ), and resin anion, while the second factor was the adsorbent materials, namely: control, activated carbon, and zeolite. The results showed that all coagulants (sodium bisulphate, alum, and resin anion), adsorbent materials (activated carbon and zeolite) and a combination of both significantly decreased the concentration of electroplating wastewater $\mathrm{Cr}$ more than $50 \%$. Resin anion and its combination with activated carbon as well as with zeolite were very effective in decreasing the concentration of electroplating wastewater $\mathrm{Cr}$ (97-98\%). Coagulant and adsorbent combination, resin anion+activated carbon and resin anion+zeolit, had double function that decreased of both Cr consentration and TDS (Total Dissolved Solid) of the concentration of electroplating wastewater.
\end{abstract}

Keywords: Chromium, coagulant, adsorbent,electroplating wastewater

\begin{abstract}
ABSTRAK
Pelaksanaan kegiatan penelitian dilakukan di Laboratorium Terpadu Balai Penelitian Lingkungan Pertanian, Jakenan, Pati, Jawa Tengah. Pengolahan limbah cair electroplating yang diambil dari Kecamatan Talang Kabupaten Tegal, Propinsi Jawa Tengah dilakukan secara kimia, yaitu melalui proses koagulasi dan flokulasi. Tujuan penelitian ini adalah untuk menguji efektivitas bahan koagulan dan adsorben dalam menurunkan konsentrasi Cr limbah cair electroplating. Percobaan menggunakan rancangan faktorial dalam rancangan acak kelompok dengan tiga ulangan. Faktor I adalah bahan koagulan, yaitu: kontrol, tawas $\left(\mathrm{Al}_{2}\left(\mathrm{SO}_{4} \times \mathrm{xH}_{2} \mathrm{O}\right)\right)$, sodium bisulfat $\left(\mathrm{NaHSO}_{4}\right)$, dan anion resin, sedangkan faktor II adalah bahan adsorben, yaitu: kontrol, arang aktif, dan zeolit. Hasil penelitian menunjukkan bahwa semua bahan koagulan (sodium bisulfat, tawas, dan anion resin), bahan adsorben (arang aktif dan zeolit) dan kombinasi keduanya nyata menurunkan konsentrasi $\mathrm{Cr}$ limbah cair electroplating lebih dari $50 \%$. Anion resin dan kombinasinya dengan arang aktif serta kombinasinya dengan zeolit sangat efektif dalam menurunkan konsentrasi Cr limbah cair electroplating (97-98\%). Kombinasi koagulan dan absorben antara anion resin+arang aktif dan anion resin+zeolit berfungsi ganda, selain menurunkan kadar Cr juga menurunkan TDS (Total Dissolved Solid) limbah cair electroplating.
\end{abstract}

Kata kunci : Kromium, koagulan, adsorben, limbah cair electroplating

\section{PENDAHULUAN}

Penggunaan koagulan tawas atau alum $\mathrm{Al}_{2}\left(\mathrm{SO}_{4}\right.$ ) (aluminium sulfat), $\mathrm{NaHSO}_{4}$ (sodium bisulfat), dan anion resin serta bahan absorben arang aktif dan zeolit sering digunakan dalam pengolahan air minum, namun sangat jarang digunakan untuk pengolahan limbah. Pengolahan limbah cair electroplating dapat dilakukan secara kimia yaitu dengan proses koagulasi (penambahan bahan kimia ke dalam air yang akan diolah) dan atau flokulasi (penggumpalan bahan terlarut, koloid, dan

${ }^{1}$ Balai Penelitian Lingkungan Pertanian J1. Raya Jakenan-Jaken Km 05, PO Box 05, Jakenan, Pati 59182E-mail: r_artantie@yahoo.com 
yang tidak dapat mengendap dalam air).

Proses koagulasi dan flukolasi yang telah dilakukan selama ini belum banyak diteliti efektivitasnya dalam menurunkan kandungan logam berat $\mathrm{Cr}$ dalam limbah cair. Limbah cair industri electroplating dapat berupa limbah organik (benzena, trikloroetilin, metil klorida, toluena, karbon tetraklorida), limbah bersifat asam $\left(\mathrm{H}_{2} \mathrm{SO}_{4}, \mathrm{HCl}\right)$ atau basa (kaustik, boraks, sodium karbonat, sabun), dan limbah yang mengandung garam logam yang beracun $(\mathrm{Cu}$, Cr, Ni, Zn, Cd, Pb, Au, Ag, Pt) (1), perlakuan tunggal koagulasi ataupun flukolasi tidak efektif untuk mengendalikan limbah yang heterogen.

Electroplating adalah proses pelapisan logam yang menggunakan arus listrik searah melalui metoda elektrolisis. Proses ini memberikan suatu penutupan logam dengan menggunakan logam-logam tertentu sebagai pelapisnya, seperti: kromium $(\mathrm{Cr})$, tembaga $(\mathrm{Cu})$, nikel $(\mathrm{Ni})$, seng $(\mathrm{Zn})$, perak $(\mathrm{Ag})$ dan lain-lain. Pelapisan logam dengan $\mathrm{Cr}$ mempunyai tujuan untuk memperoleh lapisan pelindung pada permukaan logam agar tahan terhadap gesekan, meningkatkan penampilan, memperhalus bentuk permukaan dan meningkatkan kekerasan.

Pembuangan limbah electroplating di badan-badan sungai yang berlebihan dapat meningkatkan kandungan logam berat di lingkungan termasuk limbah bahan berbahaya dan beracun, yang mengganggu baik pada tanaman, hewan maupun manusia. Keberadaan logam berat di lingkungan akan menyebabkan efek kronis dengan terjadinya bioakumulasi, perlu diwaspadai mengingat manusia adalah makhluk dengan tingkat trofik yang paling tinggi di dalam rantai makanan (2). Residu logam berat dalam tubuh bersifat kumulatif dan dapat mengganggu sistem peredaran darah, sistem syaraf dan kerja ginjal. Badan Penelitian Kanker Internasional (International Agency for Research on Cancer, IARC) mengelompokkan logam $\mathrm{Cr}$ dan Ni bersifat karsinogenik, $\mathrm{Cd}$ dan senyawanya menyebabkan kanker paru-paru, $\mathrm{Pb}$ dan senyawanya mungkin penyebab kanker (probably human carsinogens) ${ }^{(3)}$.

Pengolahan limbah cair dengan metode yang tepat tanpa efek samping diharapkan dapat meminimalisasi kandungan zat-zat polutan terutama logam berat yang berpotensi merusak lingkungan. Penggunaan bahan koagulan dan absorben secara bersama-sama diharapkan mampu meningkatkan efektivitas pemisahan logam berat $\mathrm{Cr}$ dari cairan. Keunggulan cara ini adalah selain efektif, murah, juga bahan tersebut banyak tersedia di pasar Indonesia.

Jenis koagulan yang digunakan adalah tawas atau alum $\mathrm{Al}_{2}\left(\mathrm{SO}_{4}\right)$ (aluminium sulfat), $\mathrm{NaHSO}_{4}$ (sodium bisulfat), dan anion resin. Koagulan tawas $\left(\mathrm{Al}_{2} \mathrm{~S}_{4} \cdot \mathrm{xH}_{2} \mathrm{O}\right) \mathrm{x}=11,14$, dan $\mathrm{x}$ umumnya yang digunakan adalah $18 \mathrm{H}_{2} \mathrm{O}$. Semakin banyak ikatan molekul hidrat maka semakin banyak ion lawan yang ditangkap. Pada $\mathrm{pH}<7$ terbentuk $\mathrm{Al}(\mathrm{OH})^{2+}, \mathrm{Al}(\mathrm{OH})_{2}{ }^{4+}$, $\mathrm{Al}_{2}(\mathrm{OH})_{2}{ }^{4+}$. Pada $\mathrm{pH}>7$ terbentuk $\mathrm{Al}(\mathrm{OH})^{-4}$. Flok-flok $\mathrm{Al}(\mathrm{OH})_{3}$ mengendap berwarna putih. Sodium bisulfat digunakan untuk netralisir klorin (deklorinasi) klorin dalam air dan untuk mereduksi limbah kromium heksavalen yang berbahaya menjadi kromium trivalen yang tidak berbahaya dalam indultri electroplating (4).

Untuk meningkatkan kinerja penurunan logam 
berat $\mathrm{Cr}$ pada limbah cair electroplating, maka dimanfaatkan juga adsorben. Beberapa bahan adsorben telah diketahui sebagai bahan penjerap logam berat, misalnya arang aktif dan mineral zeolit yang banyak terdapat di Indonesia. Bansal dan Goyal (5) melaporkan bahwa arang aktif mampu menghilangkan 30-99\% Cr(VI) dari larutan yang mengandung 20-200 mg/l ion $\mathrm{Cr}(\mathrm{VI})$. Daya serap arang aktif sangat bervariasi, yaitu $25-1000 \%$ terhadap berat arang aktif, dan luas permukaannya antara $300-3500 \mathrm{~m}^{2} /$ gram dan ini berhubungan dengan struktur pori internal yang menyebabkan arang aktif mempunyai sifat sebagai adsorben ${ }^{(6)}$. Tempurung kelapa merupakan bahan terbaik yang dapat dibuat menjadi arang aktif karena memiliki mikropori yang banyak, kadar abu yang rendah, kelarutan dalam air dan reaktivitas yang tinggi ${ }^{(7)}$.

Zeolit (M2nO.A12O3.ySiO2.wH2O, dimana $\mathrm{n}=$ valensi logam, $\mathrm{y}=2-200$, dan $\mathrm{w}=$ molekul air yang mengisi rongga zeolit). Mineral zeolit yang terdiri atas kristal alumino silikat terhidrasi yang mengandung kation alkali dalam kerangka tiga dimensi, memiliki rongga dan saluran yang saling berhubungan sehingga menyebabkan bagian permukaannya menjadi sangat luas dan efektif sebagai adsorben, juga memiliki muatan negatif yang dapat berinteraksi dengan senyawa atau molekul bermuatan ${ }^{(8)}$. Di bidang industri kimia, zeolit digunakan sebagai katalis, penukar ion (ion exchanger), dan sebagai penjerab (adsorben) dalam pengolahan limbah ${ }^{(9)}$.

Penelitian ini bertujuan menguji efektivitas bahan koagulan tawas $\mathrm{Al}_{2}\left(\mathrm{SO}_{4}\right)$ (aluminium sulfat), $\mathrm{NaHSO}_{4}$ (sodium bisulfat), dan anion resin dan bahan adsorben arang aktif dan zeolit serta kombinasi bahan koagulan dan absorben tersebut dalam menurunkan kadar logam berat Cr dari limbah cair electroplating.

\section{METODOLOGI}

Percobaan laboratorium dilaksanakan di Laboratorium Terpadu, Balai Penelitian Lingkungan Pertanian, Jakenan sejak September 2009 sampai Februari 2010. Percobaan menggunakan contoh limbah cair electroplating yang diambil dari Kecamatan Talang, Kabupaten Tegal. Alat-alat yang digunakan dalam penelitian ini meliputi Jartest, $\mathrm{pH}$ meter, alat-alat gelas, neraca analitik, oven, kertas saring $0.45 \mu \mathrm{m}$ dan atomic absorption spectrometer (AAS) tipe AA240FS Varian. Tiga jenis bahan koagulan yang digunakan adalah: tawas $\left(\mathrm{Al}_{2}\left(\mathrm{SO}_{4}\right.\right.$. $\left.\mathrm{xH}_{2} \mathrm{O}\right)$ ), sodium bisulfat $\left(\mathrm{NaHSO}_{4}\right)$, dan anion resin amberlite IRA402 $\mathrm{Cl}$ produksi Rohm dan Haas Amerika Serikat, sedangkan bahan adsorben yang digunakan adalah arang aktif produk Pusat Penelitian Hasil Hutan (PPH) Bogor dan zeolit agro 2000.

Pembutan arang aktif mengikuti prosedur yang dilakukan oleh Hartoyo ${ }^{(10)}$. Bahan tempurung kelapa dikarbonasi dalam retort listrik (tanpa aliran udara) pada suhu $500^{\circ} \mathrm{C}$ selama 5 jam selanjutnya ditumbuk sampai mencapai ukuran 0,3-0,5 cm, kemudian direndam dalam larutan asam fosfat selama 24 jam untuk menghilangkan bahan pengkotor yang menempel pada permukaan arang. Setelah ditiriskan diaktifkan dengan uap air panas pada suhu $900^{\circ} \mathrm{C}$ selama 60 menit.

Percobaan ini menggunakan rancangan faktorial dua faktor dalam rancangan acak kelompok dengan tiga ulangan. Faktor pertama 
adalah penggunaan koagulan, yaitu: kontrol, sodium bisulfat, tawas dan anion resin masingmasing $600 \mathrm{mg} / 1$, sedangkan faktor kedua adalah penggunaan adsorben, yaitu: kontrol, arang aktif, dan zeolit masing-masing 400 mg/l. Pengamatan dilakukan terhadap kadar Cr dalam limbah cair electroplating dengan menggunakan AAS tipe AA240FS Varian. Selain itu variabel kualitas air lainya seperti $\mathrm{pH}$ ditetapkan dengan $\mathrm{pH}$ meter, sedangkan TSS (Total Suspended Solid) dan TDS (Total Dissolved Solid) dengan cara gravimetri.

Percobaan ini menggunakan alat Jartest yang dilengkapi gelas piala ukuran $1000 \mathrm{ml}$. Contoh limbah cair electroplating dengan kadar $\mathrm{Cr} 4$ mg/l dimasukkan ke dalam gelas piala. Kemasaman larutan dipertahankan pada $\mathrm{pH} 7$ dengan menambahkan $\mathrm{H}_{2} \mathrm{SO}_{4}$ atau $\mathrm{NaOH}$. Selanjutnya ke dalam contoh limbah ditambahkan bahan koagulan dan adsorben sesuai dengan dosis dan perlakuan yang telah ditetapkan. Contoh larutan diaduk dengan kecepatan 200 rpm selama 2 menit untuk pengadukan cepat dan $20 \mathrm{rpm}$ selama 10 menit untuk pengadukan lambat. Setelah didiamkan selama 30 menit, larutan disaring, lalu kadar Cr dalam larutan ditetapkan dengan menggunakan AAS.

Persentase penurunan konsentrasi logam berat dalam air limbah dihitung menurut Hariani et al. ${ }^{(11)}$ menggunakan rumus:

\section{HASIL DAN PEMBAHASAN}

\section{Pengaruh Koagulan dan Adsorben}

Hasil percobaan seperti disajikan pada Tabel 1 menunjukkan bahwa koagulan, adsorben dan kombinasi keduanya mampu menurunkan konsentrasi logam berat $\mathrm{Cr}$ dalam limbah cair electroplating hingga lebih dari 50\%, dimana penurunan karena perlakuan kombinasi koagulan-adsorben umumnya lebih tinggi dibandingkan perlakuan tunggal. Koagulan tunggal anion resin paling tinggi menurunkan kadar $\mathrm{Cr}$ dalam larutan dibandingkankan koagulan lainnya. Kemampuan koagulan anion resin menurunkan kadar $\mathrm{Cr}$ dalam limbah mencapai 97\%, yang diikuti oleh koagulan zeolit dan tawas masing-masing adalah 71 dan $70 \%$. Kemampuan menurunkan kadar Cr yang lebih tinggi ini berkaitan dengan nilai kapasitas tukar kation (KTK) anion resin yang lebih besar pula dibandingkan dengan koagulan lainnya. Koagulan yang bermuatan negatif akan mengikat kation-kation logam $\mathrm{Cr}$ secara eletrostatik pada permukaannya sebagai kation yang tersorpsi. Nilai KTK anion resin adalah $410 \mathrm{cmol}(+) / \mathrm{kg}^{(12)}$, sedangkan nilai KTK zeolit adalah $119 \mathrm{cmol}(+) / \mathrm{kg}^{(13)}$.

Kombinasi koagulan-adsorben hanya mampu meningkatkan efektivitas penurunan kadar $\mathrm{Cr}$ dalam limbah dari 1,8 hingga 39\% dibandingkan perlakuan tunggal. Perlakuan kombinasi anion resin + zeolit menghasilan tingkat penurunan kadar $\mathrm{Cr}$ dalam limbah

$$
\% \mathrm{C}=\frac{C_{\text {awal }}-C_{\text {akhir }}}{C_{\text {cwal }}} \times 100
$$

\footnotetext{
Keterangan:

$\% \mathrm{C}=$ persentase penurunan konsentrasi $\mathrm{Cr}$

$\mathrm{C}_{\text {awal }}=$ konsentrasi $\mathrm{Cr}$ air limbah sebelum perlakuan

$\mathrm{C}_{\text {akhir }}=$ konsentrasi $\mathrm{Cr}$ air limbah setelah perlakuan
} 
Tabel 1. Persentasi Penurunan Konsentrasi Cr Limbah Cair Electroplating Menggunakan Bahan Adsorben dan Koagulan

\begin{tabular}{cccc}
\hline Perlakuan tunggal & Penurunan $\mathrm{Cr}(\%)$ & Perlakuan kombinasi & Penurunan $\mathrm{Cr}(\%)$ \\
\hline Kontrol & 0 & Sodium + arang aktif & 54 \\
Sodium bisulfat & 53 & Sodium + zeolit & 78 \\
Tawas & 70 & Tawas + arang aktif & 81 \\
Anion resin & 97 & Tawas + zeolit & 77 \\
Arang aktif & 58 & Anion resin + arang aktif & 97 \\
Zeolit & 71 & Anion resin + zeolit & 98 \\
\hline
\end{tabular}

tertinggi yaitu 98\%, diikuti oleh kombinasi anion resin + arang aktif, tawas + arang aktif, sodium + zeolit, dan tawas + zeolit menurunkan konsentrasi Cr lebih dari 70 $\%$ yaitu berturut-turut: $97,81,78$, dan $77 \%$ (Tabel 1). Kombinasi anion resin + zeolit selain dapat meningkatkan KTK juga menambah luas permukaan sehingga daya sorpsinya juga meningkat.

Adsorben silikat (zeolit) sangat efektif jika dikombinasi dengan bahan koagulan lainnya. Hasil penelitian serupa dengan penelitian Li et al. ${ }^{(14)}$ yang melaporkan bahwa penggunaan adsorben silikat dan koagulan tawas efektif menurunkan konsentrasi logam berat $\mathrm{Pb}$ dan Cr hingga mencapai 99\%, demikian juga Halimoon dan Yin ${ }^{(15)}$ juga melaporkan bahwa penggunaan adsorben zeolit dan penambahan koagulan tawas mampu menurunkan logam berat $\mathrm{Pb}, \mathrm{Cu}, \mathrm{Cd}$, dan $\mathrm{Cr}$ hingga lebih dari 50\% pada limbah cair dari industri tekstil.

Hasil uji beda nyata jujur (BNJ) pada taraf 5\% menunjukkan bahwa bahan koagulan dan adsorben masing-masing sangat nyata dan nyata dalam menurunkan $\mathrm{Cr}$ limbah cair electroplating (Tabel 2). Selanjutnya analisis sidik ragam interaksi kedua faktor tersebut tidak berpengaruh nyata terhadap variabel yang diuji. Hal ini menunjukkan bahwa perlakuan koagulan dan adsorben masingmasing memberikan respon positif terhadap persentase penurunan $\mathrm{Cr}$.

Koagulan dan kombinasinya dengan adsorben mampu menurunkan konsentrasi Cr dalam limbah cair electroplating hingga di bawah

Tabel 2. Hasil Analisis Sidik Ragam Pengaruh Koagulan, Adsorben, dan Kombinasinya Terhadap $\mathrm{Cr}, \mathrm{pH}$, dan TSS Limbah Cair Electroplating

\begin{tabular}{|c|c|c|c|c|c|c|c|}
\hline \multirow{2}{*}{ Sumber Variasi } & \multirow{2}{*}{$\mathrm{Db}$} & \multicolumn{3}{|c|}{ Kuadrat Tengah } & \multicolumn{3}{|c|}{ F hitung } \\
\hline & & $\mathrm{Cr}$ & $\mathrm{pH}$ & TSS & $\mathrm{Cr}$ & $\mathrm{pH}$ & TSS \\
\hline Koagulan (K) & 3 & 7,64 & 32,12 & $222.797,2$ & $8,49^{* *}$ & $210,83^{* *}$ & $570,00^{* *}$ \\
\hline Adsorben (A) & 2 & 3,37 & 0,03 & $2.317,2$ & $3,75^{*}$ & 0,22 tn & $5,93^{* *}$ \\
\hline $\mathrm{K} \times \mathrm{A}$ & 6 & 1,53 & 0,01 & $1.577,6$ & $1,70^{\text {tn }}$ & $0,06^{\text {tn }}$ & $4,04^{* *}$ \\
\hline Eror & 24 & 21,59 & 3,66 & 2905.3 & & & \\
\hline Total & 35 & & & & & & \\
\hline
\end{tabular}


ambang batas maksimumnya (Gambar 1). Anion resin efektif dalam menurunkan konsentrasi $\mathrm{Cr}$ limbah cair hingga 0,11 ppm, konsentrasi ini berada di bawah ambang batas maksimum yang ditetapkan oleh Kepmen LH No. 51/MENLH/10/1995 yaitu $0,5 \mathrm{ppm}$. Kombinasi anion resin+zeolit dan anion resin+arang aktif mampu menurunkan konsentrasi $\mathrm{Cr}$ air berturut-turut hingga 0,09 dan 0,12 ppm.

Hasil analisis kandungan $\mathrm{Cr}$ dalam limbah cair setelah perlakuan adsorben tunggal menunjukkan bahwa zeolit lebih baik dalam menurunkan $\mathrm{Cr}$ dibanding arang aktif. Zeolit mampu menurunkan kandungan $\mathrm{Cr}$ dalam limbah hingga $71 \%$, sedangkan arang aktif hanya mampu menurunkan $\mathrm{Cr}$ sebesar $58 \%$. Zeolit efektif untuk memisahkan partikel bermuatan negatif seperti $\mathrm{Cr}, \mathrm{Fe}, \mathrm{Pb}, \mathrm{Cd}$, dan $\mathrm{Zn}$ dari limbah cair (16) sedangkan karbon aktif efektif untuk memisahkan partikel-partikel organik ${ }^{(17)}$. Selanjutnya hasil analisis kandungan Cr limbah cair setelah perlakuan kombinasi adsorben dan koagulan menunjukkan bahwa kombinasi anion resin + zeolit dan anion resin + arang aktif paling baik dalam menurunkan Cr dibanding lainnya. Kombinasi anion resin + zeolit dan anion resin + arang aktif mampu menurunkan kandungan Cr dalam air berturut-turut hingga 97\% dan 98\%. Sementara kombinasi sodium bisulfat + arang aktif, tawas + zeolit, sodium bisulfat + zeolit dan tawas + arang aktif hanya mampu menurunkan $\mathrm{Cr}$ berturut-turut 54\%, 77\%, 78\% dan $81 \%$.

\section{pH, TSS dan TDS}

Pengukuran setelah proses koagulasi dan flokulasi menunjukkan bahwa suhu air

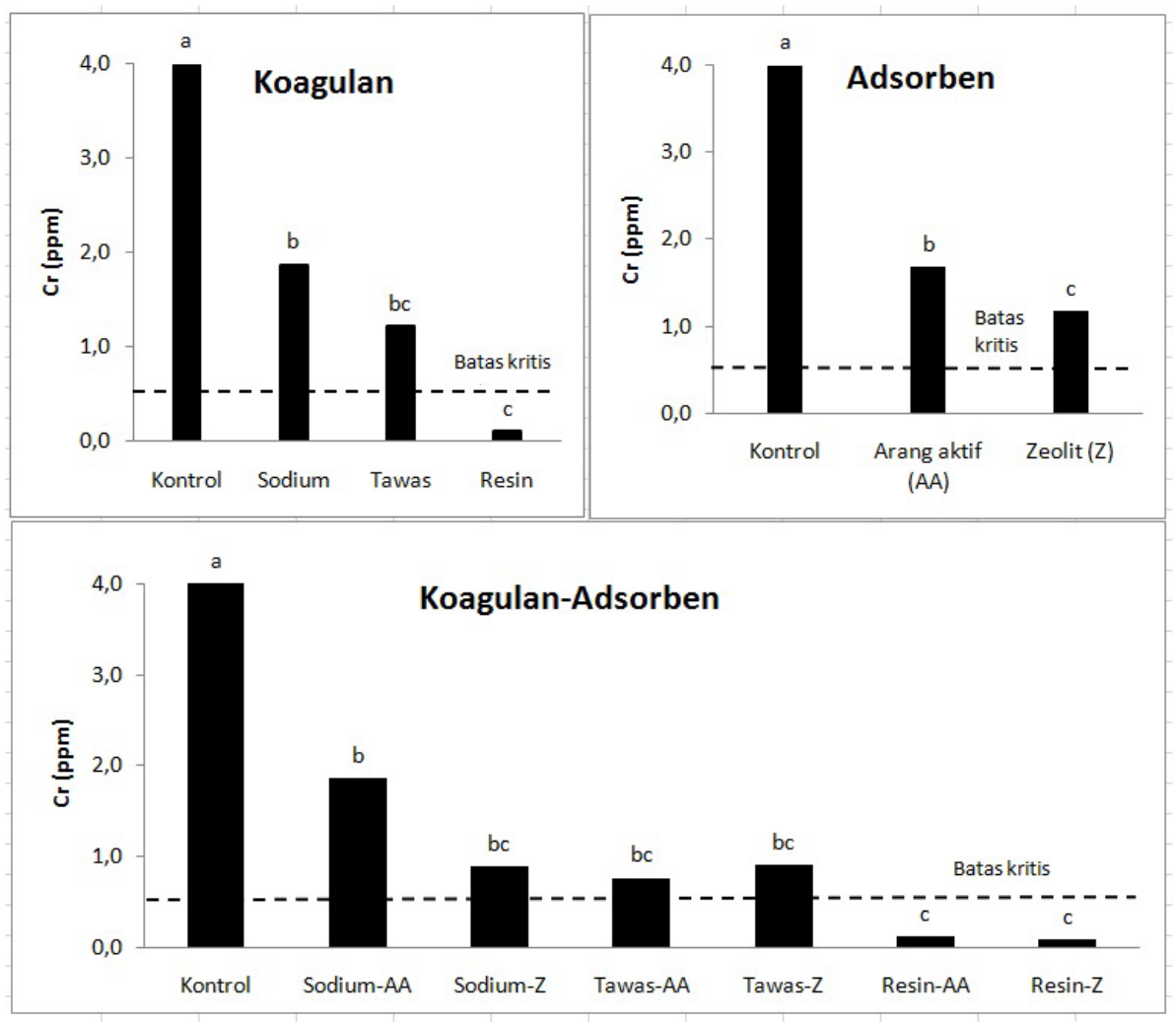

Gambar 1. Pengaruh Koagulan, Adsorben, dan Kombinasi Koagulan-Adsorben Terhadap Konsentrasi Cr Limbah Cair Electroplating 
berkisar antara $28,4-29,5^{\circ} \mathrm{C}$ atau berada pada suhu normal. Nilai keasaman $(\mathrm{pH})$ air setelah perlakuan berkisar antara 3,8-8,4. Pengaruh koagulan, adsorben, dan kombinasinya terhadap $\mathrm{pH}$ limbah cair electroplating disajikan pada Gambar 2. Gambar tersebut menunjukkan bahwa tawas nyata menurunkan $\mathrm{pH}$ limbah cair dari sekitar $\mathrm{pH} 7$ (netral) menjadi pH 3,9 (asam), sedangkan sodium tidak nyata. Adsorben yaitu arang aktif dan zeolit tidak berpengaruh nyata terhadap variabel $\mathrm{pH}$ limbah cair. Kombinasi tawas + arang aktif dan tawas + zeolit nyata menurunkan $\mathrm{pH}$ limbah cair.

Hasil analisis sidik ragam menunjukkan bahwa koagulan berpengaruh nyata $(\mathrm{P}<0,05)$ terhadap $\mathrm{pH}$ limbah cair sedangkan adsorben dan kombinasinya dengan koagulan tidak berpengaruh nyata, dengan demikian maka penggunaan tawas untuk pengolahan atau remediasi limbah cair ini perlu hati-hati, karena meskipun efektif menurunkan konsentrasi $\mathrm{Cr}$ limbah cair tapi juga dapat meningkatkan kemasaman. Tawas merupakan senyawa garam yang bersifat asam $\left(\mathrm{Al}_{2} \mathrm{SO}_{4}\right)$ karena berasal dari basa lemah $\left(\mathrm{Al}(\mathrm{OH})_{3}\right)$ dan asam kuat $\left(\mathrm{H}_{2} \mathrm{SO}_{4}\right)$. Penggunaan bahan lainnya seperti sodium bisulfat, anion resin, arang aktif dan zeolit relatif aman karena tidak berpengaruh nyata terhadap $\mathrm{pH}$ limbah cair.

Hasil pengukuran TSS limbah cair setelah proses koagulasi dan flokulasi berkisar antara 33-230 mg/l. Penggunaan koagulan sodium bisulfat dan anion resin masing-masing nyata

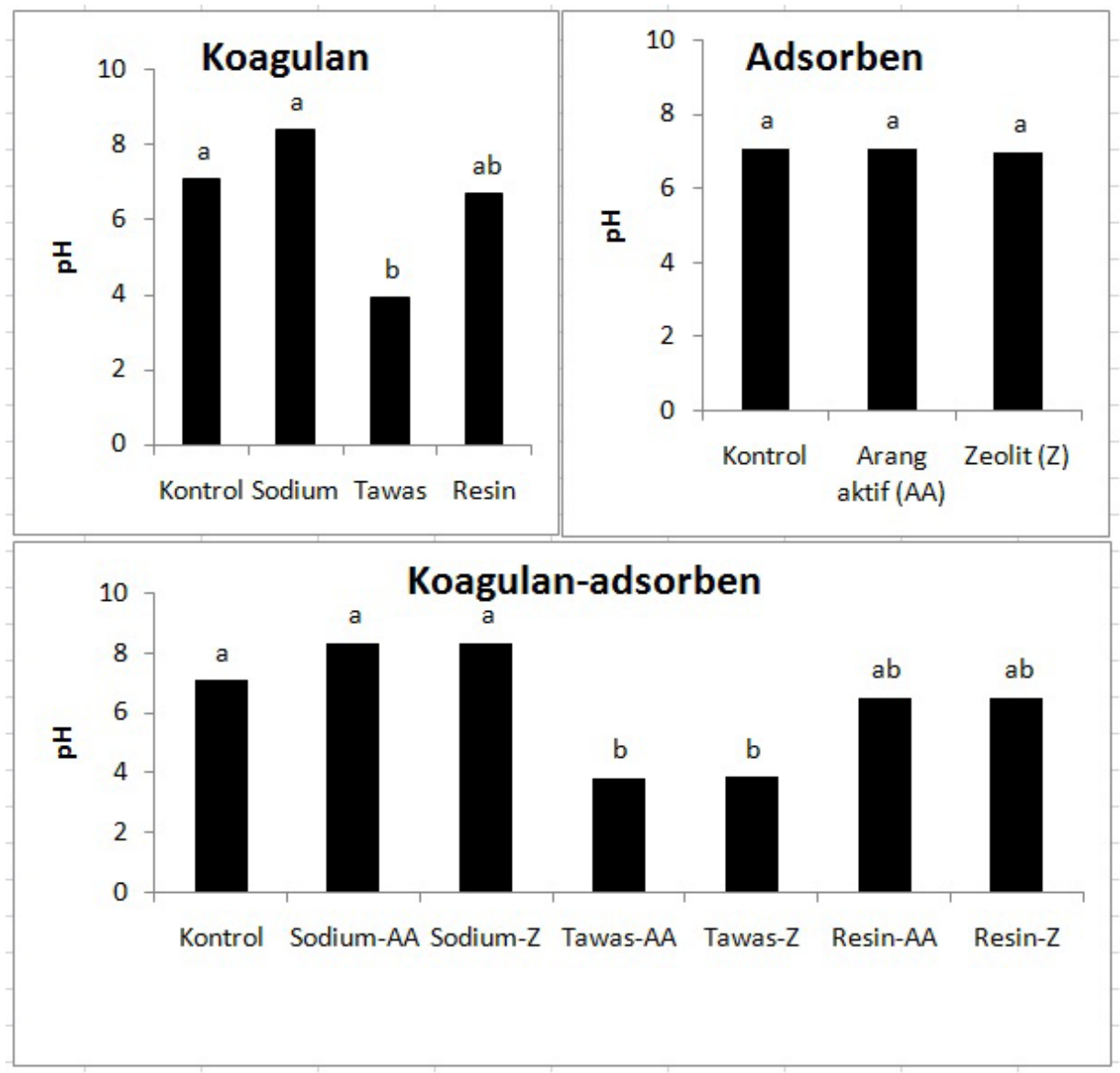

Gambar 2. Pengaruh Koagulan, Adsorben, dan Kombinasi Koagulan-Adsorben Terhadap pH Limbah Cair Electroplating 
meningkatkan TSS limbah cair, sedangkan tawas nyata menurunkan TSS limbah cair $(\mathrm{P}<0,05)$. Penggunaan adsorben arang aktif dan zeolit tidak berpengaruh nyata terhadap TSS limbah cair. Selanjutnya kombinasi tawas + zeolit, anion resin + arang aktif, dan anion resin + zeolit nyata meningkatkan TSS limbah cair (Gambar 3). Hasil analisis sidik ragam menunjukkan bahwa bahan koagulan berpengaruh sangat nyata terdap TSS limbah cair, sedangkan bahan adsorben dan kombinasinya dengan bahan koagulan tidak berpengaruh nyata (Tabel 2). Penggunaan sodium bisulfat, anion resin, dan zeolit perlu hati-hati juga karena dapat meningkatkan TSS limbah cair.

Hasil pengukuran TDS setelah proses koagulasi dan adsorpsi menunjukkan bahwa TDS limbah cair berkisar antara 18-374 mg/l. Penggunaan koagulan sodium bisulfat dan tawas masing-masing nyata meningkatkan TDS limbah cair, sedangkan anion resin tidak nyata. Penggunaan adsorben arang aktif nyata meningkatkan TDS limbah cair, sedangkan zeolit tidak nyata. Selanjutnya kombinasi antara sodium bisulfat + arang aktif, sodium bisulfat + zeolit, tawas + arang aktif, dan tawas + zeolit nyata meningkatkan TDS limbah cair (Gambar 4). Perlakuan sodium bisulfat menghasilkan nilai TDS paling tinggi dibandingkan perlakuan lainnya. Tetapi nilai ini masih jauh di bawah batas maksimum yang ditetapkan sebagai limbah cair industri menurut Kepmen LH No. 51/ MENLH/10/1995, yaitu 2.000 mg/l.

\section{KESIMPULAN}

Semua bahan koagulan (sodium bisulfat, tawas, dan anion resin) yang diujikan mampu

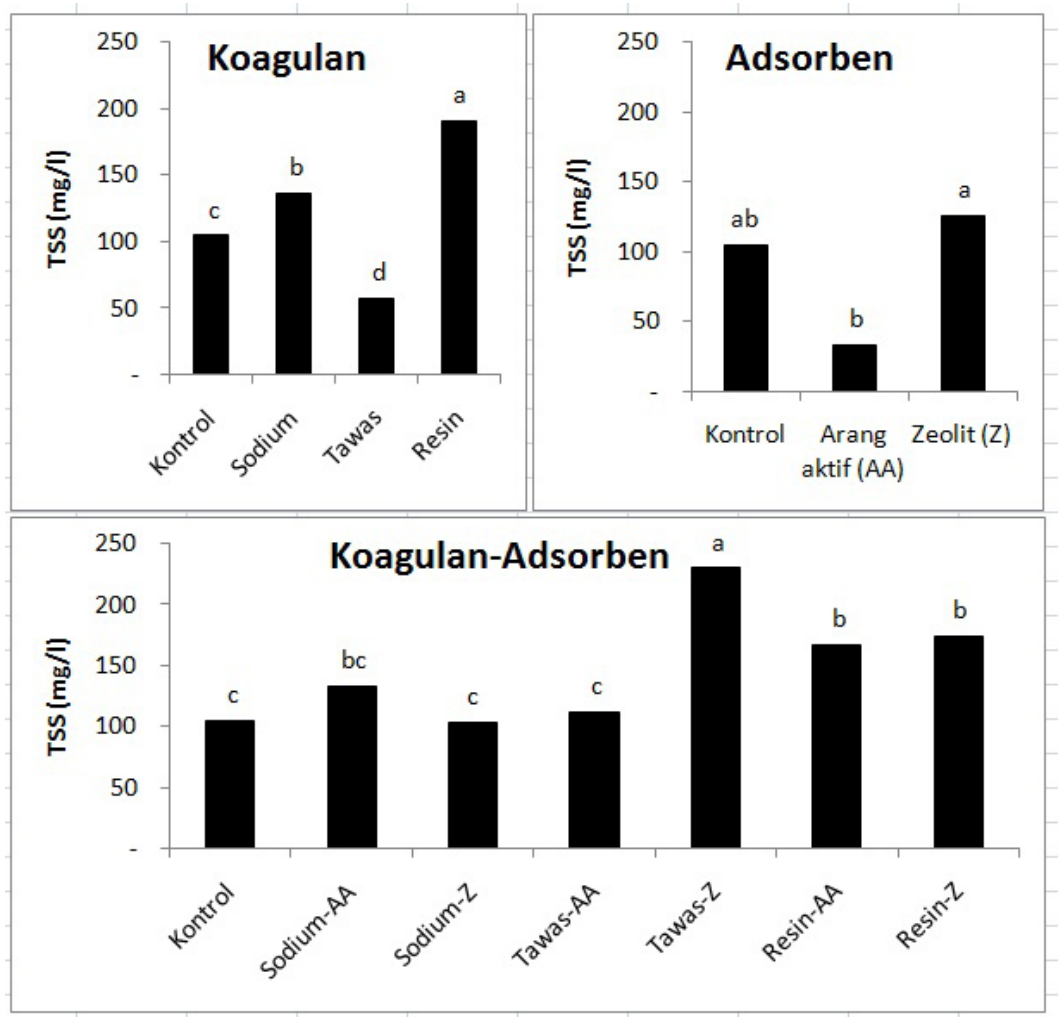

Gambar 3. Pengaruh Koagulan, Adsorben, dan Kombinasi Koagulan-Adsorben Terhadap TSS Limbah Cair Electroplating 


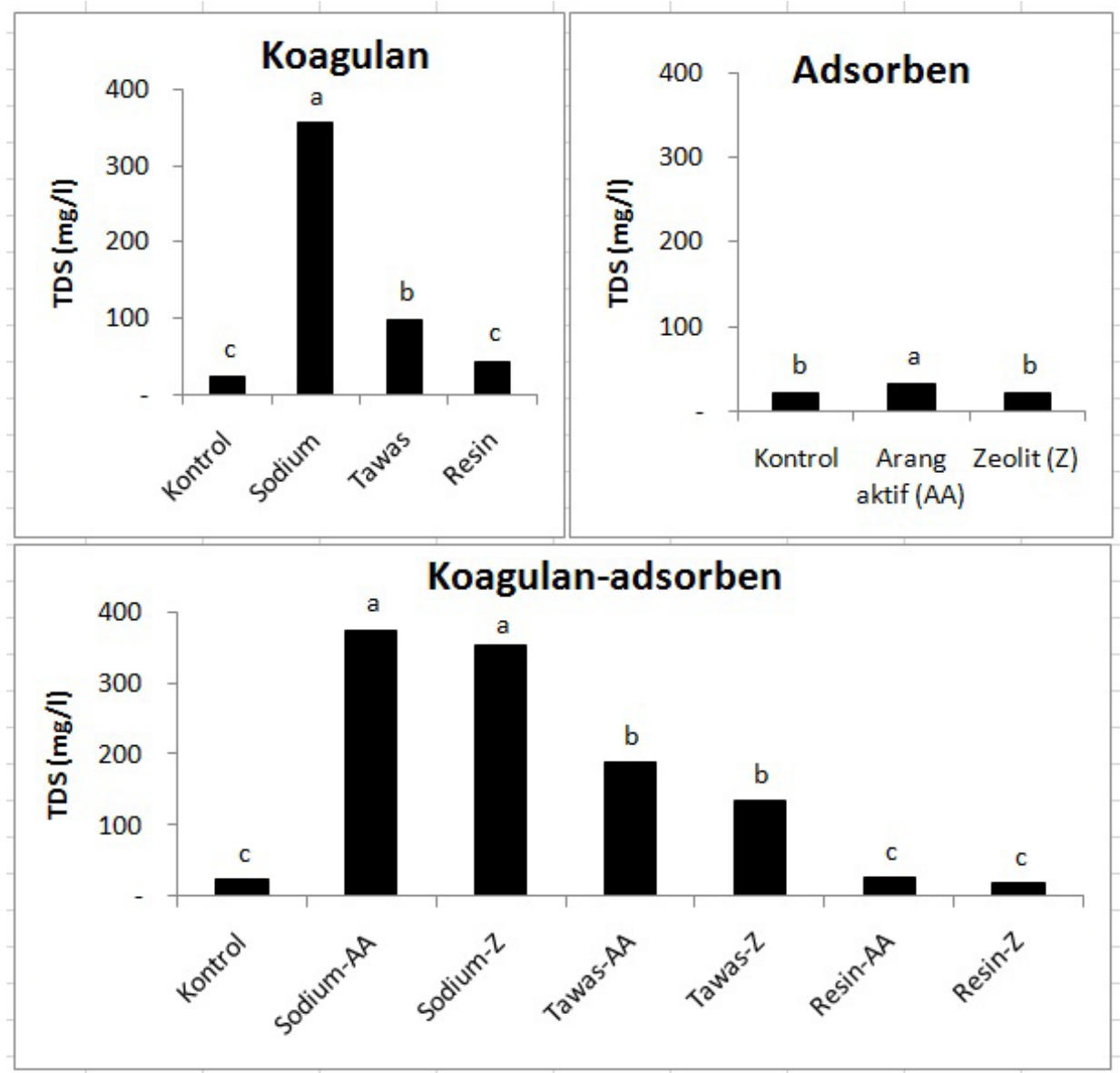

Gambar 4. Pengaruh Koagulan, Adsorben, dan Kombinasi Koagulan-Adsorben Terhadap TDS Limbah Cair Electroplating

menurunkan konsentrasi $\mathrm{Cr}$ limbah cair electroplating lebih dari 50\% (53-97\%).

Kombinasi koagulan dan absorben menurunkan konsentrasi $\mathrm{Cr}$ cair electroplating pada nilai rentang $94-98 \%$.

Kombinasi koagulan dan absorben antara anion resin + arang aktif dan anion resin + zeolit berfungsi ganda, selain menurunkan kadar Cr juga menurunkan TDS limbah cair electroplating.

\section{DAFTAR PUSTAKA}

1. Mulyadi, S.Y. Jatmiko dan A.N. Ardiwinata. 2007. Pencemaran Limbah Industri di Lahan Pertanian dan Teknologi Penanggulangannya Hal. 130-192 dalam A.M. Fagi, E. Pasandaran dan U. Kurnia (Eds). Pengelolaan Lingkungan Pertanian Menuju Mekanisme Pembangunan Bersih. Pati: Balai Penelitian Lingkungan Pertanian, Badan Penelitian dan Pengembangan Pertanian.

2. Lubis. 2002. Ancaman Logam Berat Menjelang Musim Hujan. Rangkuman Analisis. Sinar Harapan Bekerjasama dengan Lingkar-324 dan Environmental Empowering Forum (EEFOR).

3. Nordberg, G., B.A. Fowler, M. Nordberg, and L. Friberg. 2007. Handbook on The Ttoxicology of Metals. Copenhagen: Academic Press. 
4. Markon. 2006. Hexavalent Chrome Waste Teatment. http://www.sensorex. com/docs /AppNoteChromeWaste.pdf. Diakses tanggal 10 Oktober 2011.

5. Bansal, R.C. and M. Goyal. 2005. Activated Carbon Adsorption. Boca Raton: CRC Press, Publ.

6. Sembiring, M.T., dan T.S. Sinaga. 2003. Arang Aktif Pengenalan dan Proses Pembuatannya. USU digital library.

7. Subadra, I., B. Setiaji, I. Tahir. 2005. Activated Carbon Production from Coconut Shell with $\left(\mathrm{NH}_{4}\right) \mathrm{HCO}_{3}$ Activator as an Adsorbent In Virgin Coconut Oil Purification. Prosiding Seminar Nasional DIES ke 50 FMIPA UGM. 1-8.

8. Flanigen, M., R.W. Broach, and S.T. Wilson. 2010. Molecular Sieves and Zeolites. Page 1-26 in S. Kulprathipanja ed. Zeolites in Industrial Separation and Catalysis. Wiley-VCH Verlag $\mathrm{GmbH} \& \mathrm{Co}$. KGaA, Weinheim, Glasgow.

9. Ulfah, E.M., F.A. Yasnur, dan Istadi. 2006. Optimasi Pembuatan Katalis Zeolit X dari Tawas, $\mathrm{NaOH}$ dan Water Glass dengan Response Surface Methodology. Bulletin of Chemical Reaction Engineering \& Catalysis. 1(3): 26-32.

10. Hartoyo, 1983. Pemanfaatan Limbah Kayu untuk Briket Arang. Prosiding Seminar Pemanfaatan Energi Biomass. Puslitbang Hasil Hutan.
11. Hariani, P.L., N. Hidayati, dan M. Oktaria. 2009. Penurunan Konsentrasi Cr(VI) Dalam Air dengan Koagulan $\mathrm{FeSO}_{4}$. Jurnal Penelitian Sains. Jurnal Penelitian Sains, Vol. 12 2(C) 12208.

12. Bilgen, M. 2009. Wrinkle Recovery for Cellulosic Fabric by Means of Ionic Crosslinking. Journal of Industrial Textiles. January 2009 39: 57-80.

13. (Al-Jabri. 2008. Kajian Metode Penetapan Kapasitas Tukar Kation Zeolit sebagai Pembenah Tanah Untuk Lahan Pertanian Terdegradasi. Jurnal Standardisasi. Vol. 10 No.2 Tahun 2008. Badan Standardisasi Nasional.

14. Li, F.T., X.Li, B.R. Zhang, and Q.H. Ouyang. 2004. Removal of Heavy Metals in Effluent by Adsorption and Coagulation. Chinese Chemical Letters 15: 83-86.

15. Halimoon, N., and R.G.S. Yin. 2010. Removal of Heavy Metals from Textile Wastewater using Zeolite. Environment Asia 3: 124-130.

16. Wingenfelder, U., C. Hansen, G. Furrer and R. Schulin. 2005. Removal of Heavy Metals from Mine Waters by Natural Zeolites. Environ. Sci. Technol. 39: 4606-4613.

17. Chiang, C.C. and K. Megonnell, 2005. Ion Exchange Technologies for Perchlorate Removal from Drinking Water are Evolving. http://www. calgoncarbon.com/ion_exchange/ documents/PerchlorateWhitePaper_ CANV.pdf. Diakses tanggal 10 Oktober 2011. 